\title{
Review on Live animal and Meat Marketing and Production in Ethiopia
}

\author{
Rozina Gidey \\ Ethiopian Institute of Agricultural Research (EIAR)
}

\begin{abstract}
This paper reviews research works done on livestock and meat marketing opportunities and challenges in Ethiopia. Moreover, this paper has tried to assess secondary data collected from Ethiopian custom and revenue authority (ECRA) and central statistical agency (CSA) in order to analyze the export and to get a more insight on the livestock production system by smallholders. Live animal and meat export to Middle East and neighboring countries is increasing. The increasing number of live animal and meat exporter, geographic proximity to the Middle East countries, economic growth, government interest and support to the sub sector gives the country comparative advantages in livestock and livestock product trading. However, traditional production system, poor market infrastructure, lack of market information and extension service, trans-boundary disease outbreaks, long and complicated market chain, and illegal cross border trade are affecting the sub-sector performance to the economy and livelihood improvement.
\end{abstract}

Keywords: Live animal, Meat, Marketing, Export, Production

DOI: $10.7176 / \mathrm{JMCR} / 77-02$

Publication date:March $31^{\text {st }} 2021$

\section{Introduction}

In Ethiopia, agriculture is the mainstay of the economy, contributing about $35 \%$ to GDP and $68 \%$ to employment, and $90 \%$ of export value (FDRE, 2016). The country's agricultural sector is heterogeneous, comprising small through medium to large farmers and farms with different levels of efficiency; however, smallholders dominate the agricultural and livestock production landscape (FAO, 2019).

Livestock is an integral part of agriculture, accounting for about $45 \%$ to the total value of agricultural production and supporting the livelihoods of a large share of the population (FAO, 2019). Depending on agroecological zones, the livestock sector is estimated to contribute directly and indirectly to the livelihood of 60$70 \%$ of the population and between 37-87 \% of households' income (Brasesco et al, 2019).

Ethiopia has the largest livestock population in Africa, the national herd comprises 61 million cattle, 33 million sheep, 39 million goat, 59 million chicken and 1.76 million camels (CSA, 2019). The livestock sector is a major contributor to export earnings and contribute about $10 \%$ to total export earnings, of which $69 \%$ accounted for by live animal exports (FAO, 2019) though the export volumes are not increasing as much as anticipated given the huge livestock resources present in the country (Brasesco et al, 2019).

Apart from income generation, the livestock sector uses as power for crop cultivation, means of transportation, manure for farmland and household energy, security in times of crop failure, and means of wealth accumulation for the rural householders (Ashenafi and Geoffrey, 2016).

Though, the country livestock management system is predominated by extensive production systems. As a result, the sub sector is constrained by several factors, including poor market infrastructure, lack of market information and extension service, traditional production system that result in low production and low reproductive performance, trans-boundary disease outbreaks, long and complicated market chain, and illegal cross border trade.

Therefore, the main objective of this paper is to review research works on the production and marketing challenges and opportunities of livestock and livestock products. Moreover, trends in live animal and meat export is assessed based on secondary data collected from Central statistics agency (CSA) and Ethiopian custom and revenue authority (ECRA).

\section{Livestock herd characteristics}

According to the CSA estimate $63.1 \%$ of the cattle herds consisted of 3 - 10 year old animals (Table 1). For sheep and goats, $52.7 \%$ and $51.9 \%$ of their respecting herds were more than two years old.

Cattle kept by the rural household for milk production, draught use, beef production, breeding and other purposes. The highest proportion of cattle over three years of age has been kept mainly for draught use, followed by breeding and milking (CSA, 2019). While sheep and goats aged more than two years are kept mainly for breeding purpose.

The cattle herd structure is featured by a relatively higher proportion of male/ oxen which confirm that the main reason for keeping cattle is for draught use, although this figure is dominated in in the highland areas of Ethiopia (Negassa and Jabbar, 2008; Gebremariam et al.,2013). In contrast, in lowland pastoral areas cattle 
mostly kept for milk and meat production.

Table 1. Distribution of livestock population in smallholder farms

\begin{tabular}{lcccc}
\hline \multicolumn{1}{c}{ Age category } & Cattle $(\%)$ & Age category & Sheep $(\%)$ & Goat $(\%)$ \\
\hline$<6$ months & 9.3 & $<6$ months & 25.6 & 24.32 \\
6 months - 1 year & 8.8 & 6 months - 1 year & 10.8 & 12.12 \\
$1-3$ years & 16.8 & $1-2$ years & 10.9 & 12.68 \\
$3-10$ years & 63.1 & 2 years \& older & 52.7 & 50.88 \\
10 years \& older & 2.1 & & & \\
\hline
\end{tabular}

Source: Own computation based on CSA (averaged from 2014/15 to 2018/19)

\section{Livestock herd dynamics}

Negassa and Jabbar (2008) stated that majority of smallholders obtain their livestock through births from the current herd and purchases from the market; whereas birth is much more important than market purchase in building and maintaining herd size. As presented below the inflow of cattle population through births is $67 \%$ and for sheep and goat the inflow though birth is $70 \%$ and $80 \%$, respectively (Table 2 ). The inflow through purchase is more for cattle which accounts for $28 \%$ while for sheep and goats it accounts for $27 \%$ and $17 \%$.

Sales, deaths, slaughters, gifts, and thefts are the major components of livestock outflows (Asfaw et al., 2011). Sales and deaths are the major components of cattle outflows which accounts for $56 \%$ and $34 \%$, respectively. For sheep and goats, sales, deaths and on-farm slaughters are the major components of outflows. Sales account for $42 \%$ and $40 \%$ of sheep and goats outflows, respectively, while deaths account for $32 \%$ and $39 \%$.

Table 2. Herd dynamics in livestock production system

\begin{tabular}{lccc}
\hline & Cattle & Sheep & Goat \\
\cline { 2 - 4 } & Number (million) & Number (million) & Number (million) \\
\hline \multicolumn{1}{c}{ Inflows } & & & \\
Birth & $11.22(67)$ & $13.12(70.3)$ & $13.10(80.6)$ \\
Purchase & $4.69(28)$ & $4.98(26.7)$ & $2.7(16.6)$ \\
Other & $0.83(5)$ & $0.55(3)$ & $0.45(2.8)$ \\
Total Inflows & 16.74 & 18.66 & 16.25 \\
\multicolumn{1}{c}{ Outflows } & & & \\
Sale & $6.59(56.2)$ & $7.05(42.7)$ & $5.95(40.3)$ \\
Slaughter & $0.45(3.8)$ & $3.84(23.3)$ & $2.6(17.6)$ \\
Death & $4(34.1)$ & $5.25(31.8)$ & $5.79(39.3)$ \\
Other & $0.68(5.8)$ & $0.36(2.2)$ & $0.42(2.8)$ \\
Total outflows & 11.72 & 16.5 & 14.75 \\
\hline
\end{tabular}

Source: Own computation based on CSA (averaged from 2014/15 to 2018/19); Values in bracket are shares (\%) in livestock flow

\section{Livestock production systems}

The Ethiopian livestock population is almost entirely composed of indigenous animals. Recent estimates from the CSA show that $97.92 \%, 1.86 \%$, and $0.22 \%$ of cattle are indigenous, hybrid, and exotic breeds, respectively; the respective estimates for sheep are $99.72 \%, 0.27 \%$, and $0.01 \%$. Nearly all goats $(99.98 \%)$ are indigenous breeds (CSA, 2019). Improved breeds adoption showed insignificant change over time.

In Ethiopia, there are three predominant livestock management systems: intensive management, mixed crop-livestock, and pastoral/agro-pastoral. The intensive management system is recently growing market oriented dairy and poultry farms practiced in urban and peri-urban areas. In the intensive management system, exotic breeds or crossbred animals are mainly kept for their high performance (Tegegne et al., 2013). The mixed crop-livestock farming system is the dominant livestock production system in the Ethiopian highlands. The diversification in this system allows producers to mitigate the risk of crop failure or losses of livestock, while livestock is also an important input to crop production and vice versa (Yisehak, 2008). Hence the percentage of 
farmers growing only crop and farmers keeping only livestock is decreased and the percentage of farmers with both crop and livestock holdings was increase from $74 \%$ in 2001/02 to 86\% in 2007/08 (Asfaw et al., 2011). The pastoral and agro-pastoral production system is practiced in southern and eastern parts of the country. In the pastoral system, there is no crop production, while agro-pastoralism is characterized by dominance of livestock husbandry and limited crop production (Tegegne et al., 2013). In the latter two livestock production systems women play a significant role.

\section{Domestic meat consumption patterns}

In Ethiopia most of the livestock products like meat, milk, egg, butter, and cheese are consumed in the household and marketing of livestock products is minimal. According to 2018 CSA estimate $54.7 \%$ of beef and $92.4 \%$ of mutton/ goat meat are consumed in the household, and $27.1 \%$ and $1.8 \%$ are sold, respectively. With the fast growth of both the Ethiopian economy and the population, the domestic demand for meat is increasing, however the average per capita consumption of meat is $9 \mathrm{~kg}$ per year, below the average for developing countries (i.e.25 $\mathrm{kg}$ ) (Alemayehu, 2011). This very low meat consumption is mainly driven by low rural consumption, as the average annual meat consumption in urban area is $11.5 \mathrm{~kg}$ per person, while it is $4.0 \mathrm{~kg}$ per person in rural areas (Kibrom and Ibrahim, 2012). The low consumption is due to low per capita income, high domestic meat prices, and the many fasting days of the Orthodox Christian calendar (Yilma et al., 2011; AGP-LMD, 2013; Ayenew et al., 2009). While the domestic demand for meat increases during traditional and religious festivities (Ashenafi and Geoffrey, 2016).

\section{Live animal and meat export}

Ethiopia exports both live animals and meat to the Middle East, as well as some Africa countries. Trade performance of livestock and livestock products over time is analyzed using data from Custom and Revenue Authority (ERCA) on volume and value of livestock and livestock products exported.

\subsection{Live animal Exports}

Trend in the volume and value of Ethiopian livestock exports from 2010/11 to 2019/20 is presented in Figure 1. The export showed non-uniform pattern over the years. The main live animal species exported include cattle, sheep, goats, and camels. On average around half a million live animals were exported and a total of USD 123 million earned annually. Though, the volume of live animal export represents less than one percent of the estimated total cattle, sheep, goat, and camel population of the country. In terms of the composition of live animal exports, sheep accounted for the largest export share $(55 \%)$ followed by cattle and camel, which accounted for about $26 \%$ and $11 \%$ of the total live animal exports. While the highest income is generated from cattle export followed by camel and sheep. Cattle exports accounted for $61 \%$, followed by camels which accounted for $22 \%$, and sheep which accounted for about $16 \%$ of the total value of live animal exports. The average export price in the last ten years was USD 521, USD 417 and USD 64 for cattle, camel and sheep/ goat, respectively.

Figure 1. Trends in value and volume of live animal export

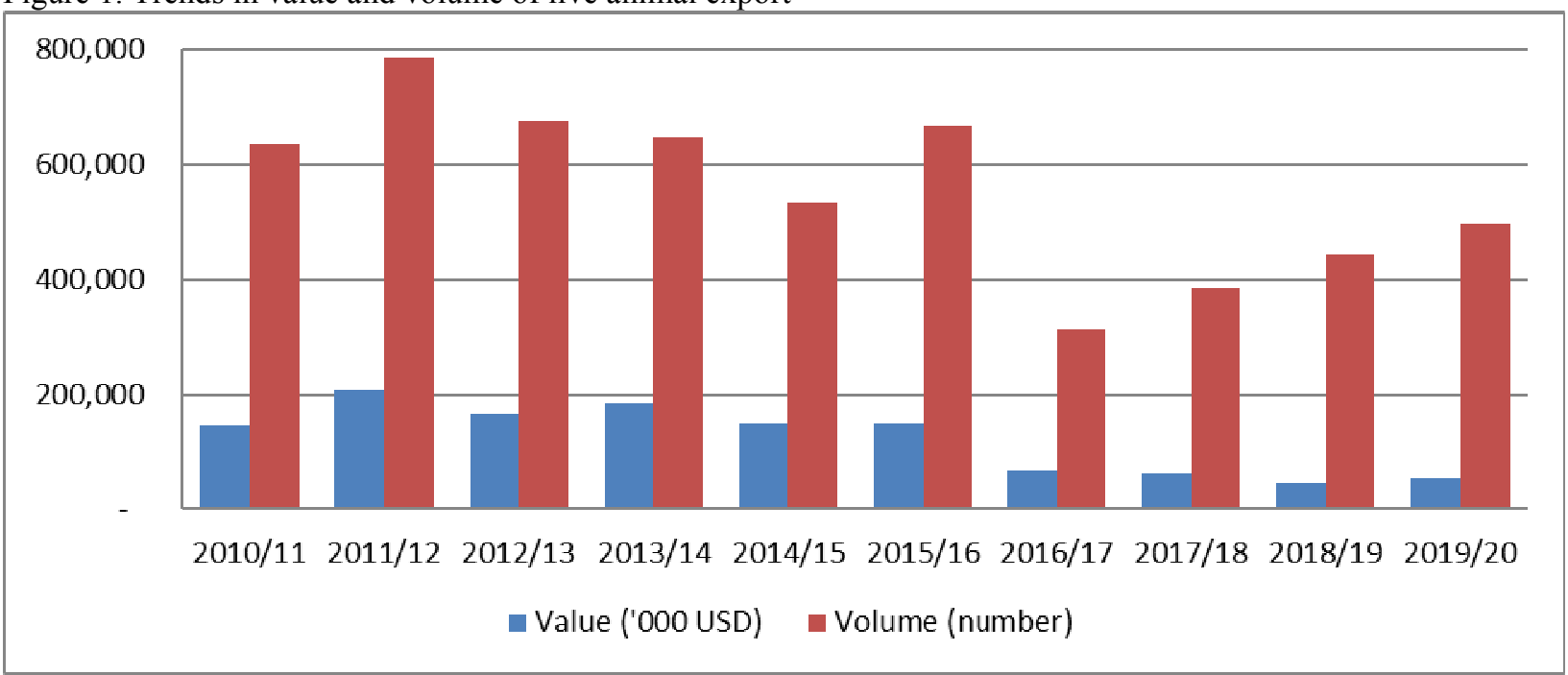

Source: Own computation based on ECRA

In terms of importing countries, Somalia is the largest exporter of Ethiopian live animal followed by Saudi Arabia, Yemen, Djibouti and Sudan. Somalia accounted for $33 \%$ of the total value of exports followed by Egypt which accounted for about $17 \%$ (Table 3). Hence, Somalia account for significant volume and value of live 
animals exports from Ethiopia.

Somalia is the top importer of Ethiopian cattle accounted for $48 \%$ of cattle export from Ethiopia followed by Sudan and Djibouti and Sudan remain in the top for Ethiopian camel export too, which accounted for 39\%. Besides studies showed that the informal marketing of live animal with Somalia, Kenya, Sudan, and Djibouti, accounts for $80-90 \%$ of the county's export of live animals (AGP-LMD, 2013), and the Ethiopian government losses about USD 300 million per annum from such illegal marketing.

Table 3 . The structure of live animal exports by destination

\begin{tabular}{|c|c|c|c|c|c|c|c|}
\hline \multirow{2}{*}{ Destination } & \multicolumn{6}{|c|}{ Export volume (number) } & \multirow{2}{*}{$\begin{array}{l}\text { Value ('000 } \\
\text { USD) }\end{array}$} \\
\hline & Cattle & Camels & Sheep & Goats & Other & Total & \\
\hline Somalia & $686,872(47.7)$ & $27,805(4.4)$ & $270,241(8.8)$ & $148,001(52.9)$ & $95,000(63.5)$ & $1,227,919(22)$ & $406,515.9(33)$ \\
\hline Egypt & $93,063(6.5)$ & $233,613(36.3)$ & $7,663(0.2)$ & $2,700(1)$ & - & $337,039(6)$ & $212,878.4(17)$ \\
\hline Yemen & $139,810(9.7)$ & $35,154(5.5)$ & $803,950(26.1)$ & $23,321(8.3)$ & - & $1,002,235(18)$ & $140,279.7(11)$ \\
\hline Sudan & $264,081(18.3)$ & $253,191(39.6)$ & $8,696(0.3)$ & $556(0.2)$ & $91(0.1)$ & $526,615(9)$ & $135,596.6(11)$ \\
\hline Djibouti & $149,583(10.4)$ & $16,128(2.5)$ & $419,496(13.6)$ & $29,626(10.6)$ & $7,457(5)$ & $622,290(11)$ & $124,790.3(10)$ \\
\hline Saudi Arabia & $27,745(1.9)$ & $20,543(3.2)$ & $931,730(30.2)$ & $29,065(10.4)$ & $4(0)$ & $1,009,087(18)$ & $92,457.8(8)$ \\
\hline UAE & $42,136(2.9)$ & $4,702(0.7)$ & $350,076(11.4)$ & $26,689(9.5)$ & - & $423,603(8)$ & $48,526.1(4)$ \\
\hline Oman & $16,603(1.2)$ & $810(0.1)$ & $44,003(1.4)$ & $5,969(2.1)$ & - & $67,385(1)$ & $13,169.8(1)$ \\
\hline Bahrain & $3,388(0.2)$ & - & $123,757(4)$ & $7,093(2.5)$ & - & $134,238(2)$ & $11,639.5(1)$ \\
\hline Kuwait & $2,160(0.1)$ & $2,077(0.3)$ & $84,513(2.7)$ & $4,460(1.6)$ & - & $93,210(2)$ & $7,491.2(1)$ \\
\hline Others & $15,809(1.1)$ & $44,795(7)$ & 40,090 (1.) & $2,514(0.9)$ & $47,025(31.4)$ & $150,233(3)$ & $38,922(3)$ \\
\hline Total & $1,441,250$ & 638,818 & $3,084,215$ & 279,994 & 149,577 & 4 & \\
\hline Share $(\%)$ & 26 & 11 & 55 & 5 & 3 & & \\
\hline
\end{tabular}

Source: Own computation based on ECRA; Values in bracket are market shares (\%) by country of destination

For sheep and goats, Saudi Arabia was the top importer, accounting for 30\% of total sheep exports and 53\% of total goat exports from Ethiopia in the last ten years. While the live animal exports to Djibouti, Yemen, Somalia, and Sudan are for re-export to other Middle Eastern countries, indicating that a large proportion of live animals are not directly exported from Ethiopia to final consumers (Asfaw et al., 2011).

\subsection{Meat exports}

Figure 2 present the trends in the volume and value of meat exports from 2010/11 to 2019/20. The total amount of meat export for the last ten years was 168,921 tons earning about a total of USD 820 million. The main meat products exported from Ethiopia are goat meat, sheep meat, beef and offal.

Figure 2. Trends in value and volume of meat exports

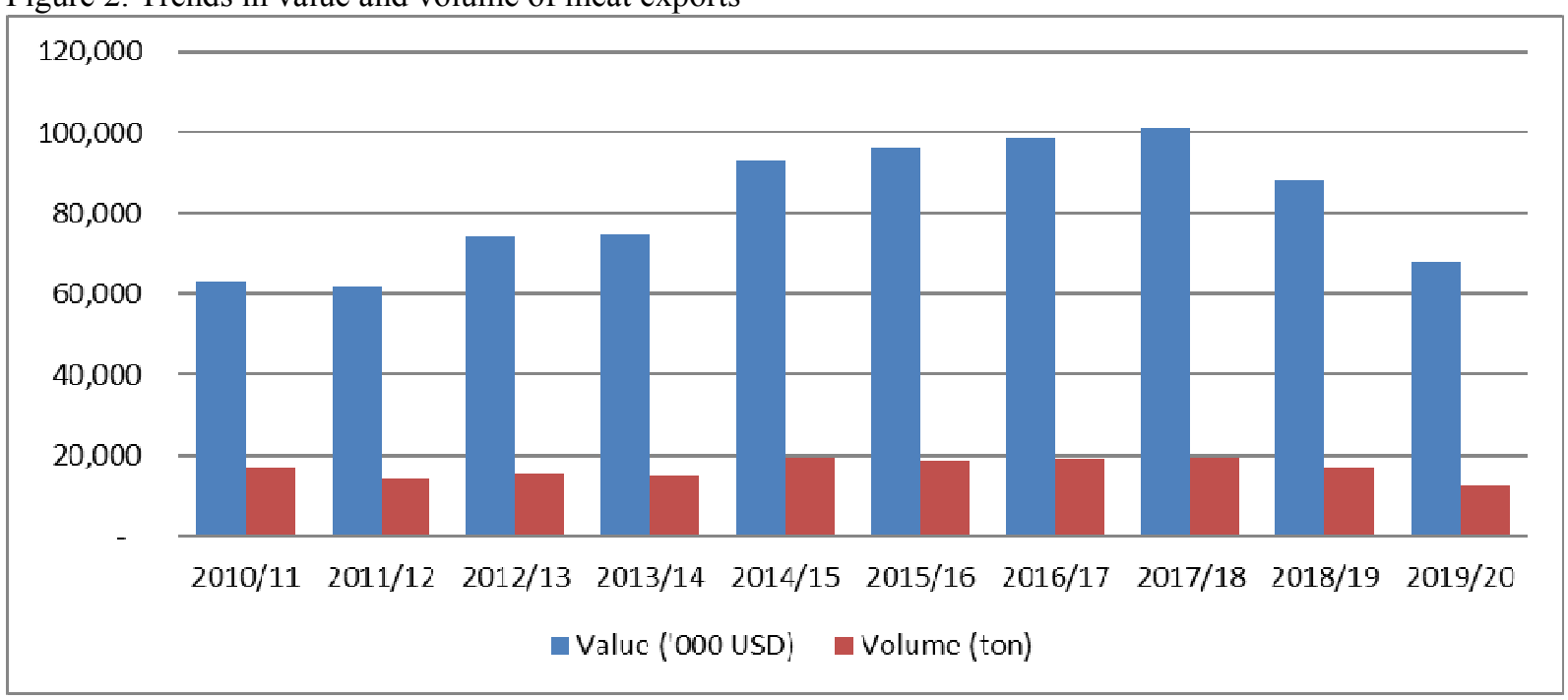

Source: Own computation based on ECRA 
The two major meat importers from Ethiopia were United Arab Emirate (UAE) and Saudi Arabia, accounted for $55 \%$ and $32 \%$ of Ethiopia's total meat exports (Table 4). In terms of volume of meat export, goat meat accounted for about $79 \%$ of the total quantity followed by offal export. In terms of the total value of meat exported, the largest share is earned from goat and sheep meat.

Table 4. The structure of meat exports by destination

\begin{tabular}{|c|c|c|c|c|c|c|c|}
\hline \multirow[b]{2}{*}{ Destination } & \multicolumn{5}{|c|}{ Volume of export (tons) } & \multirow[b]{2}{*}{ Total } & \multirow[b]{2}{*}{$\begin{array}{l}\text { Value ('000 } \\
\text { USD) }\end{array}$} \\
\hline & Goat meat & $\begin{array}{l}\text { Sheep } \\
\text { meat }\end{array}$ & Beef & $\begin{array}{l}\text { Camel } \\
\text { meat }\end{array}$ & Offal & & \\
\hline UAE & $\begin{array}{l}85,231.8 \\
(64)\end{array}$ & $\begin{array}{l}3,672.8 \\
(32.4)\end{array}$ & $\begin{array}{l}4,564.9 \\
(43.3)\end{array}$ & $1.0(2.9)$ & $9.6(0.1)$ & $\begin{array}{l}93,480.1 \\
(55)\end{array}$ & $474,269.6(58)$ \\
\hline $\begin{array}{l}\text { Saudi } \\
\text { Arabia }\end{array}$ & $\begin{array}{l}46,503.7 \\
(35)\end{array}$ & $\begin{array}{l}5,653.4 \\
(49.9)\end{array}$ & $43.6(0.4)$ & $27.2(78.2)$ & $\begin{array}{l}1,784.4 \\
(12.7)\end{array}$ & $\begin{array}{l}54,012.4 \\
(32)\end{array}$ & $289,333.6(35)$ \\
\hline Vietnam & - & $16.4(0.1)$ & $27.9(0.3)$ & - & $\begin{array}{l}4,801.3 \\
(34.2)\end{array}$ & $4,845.7(3)$ & $11,839.1(1)$ \\
\hline Bahrain & $792.6(0.6)$ & $\begin{array}{l}1,799.5 \\
(15.9)\end{array}$ & $\begin{array}{l}1,750.2 \\
(16.6)\end{array}$ & - & $43.2(0.3)$ & $4,385.4(3)$ & $18,035.8(2)$ \\
\hline Turkey & - & - & - & - & $\begin{array}{l}2,327.1 \\
(16.6)\end{array}$ & $2,327.1(1)$ & $3,179.8(0)$ \\
\hline Hongkong & - & - & $289.8(2.7)$ & - & $\begin{array}{l}2,001.5 \\
(14.2)\end{array}$ & $2,291.3(1)$ & $5,763.9(1)$ \\
\hline Sudan & - & - & $3.0(0)$ & - & $\begin{array}{l}1915.8 \\
(13.6)\end{array}$ & $1,918.8(1)$ & $953.5(0)$ \\
\hline Angola & - & - & $\begin{array}{l}1,353.7 \\
(12.8)\end{array}$ & - & - & $1,353.7(1)$ & $4,741.8(1)$ \\
\hline Egypt & - & - & $810.9(7.7)$ & - & $335.1(2.4)$ & $1,145.9(1)$ & $3,189.5(0)$ \\
\hline Kuwait & $41.2(0)$ & $68.4(0.6)$ & $527.5(5)$ & - & 0.2 & $637.4(0)$ & $2,163.4(0)$ \\
\hline Other & $398.7(0.3)$ & $115.9(1)$ & $\begin{array}{l}1169.2 \\
(11.1)\end{array}$ & $6.6(19)$ & $832.8(5.9)$ & $2523(1)$ & $7066.8(1)$ \\
\hline Total & $132,968.0$ & $11,326.4$ & $10,540.7$ & 34.8 & 14,051 & & \\
\hline Share $(\%)$ & 78.7 & 6.7 & 6.2 & 0.0 & 8.3 & 168 & $820,536.8$ \\
\hline
\end{tabular}

Source: Own computation based on ECRA; Values in bracket are market shares (\%) by country of destination

\section{Challenges and opportunities of live animal and meat marketing}

\subsection{Challenges}

Ethiopia's livestock and fisheries sector has great potential for growth and job creation and supports poverty reduction and food security; though the subsector faces a number of challenges.

Poor market infrastructure: In Ethiopia, about 120 livestock market centers are recognized by the government, but most of the centers are not well organized to provide watering, feeding, resting, and quarantine facilities; the situation is worse in pastoral areas (Anteneh et al., 2010). Primary, secondary and tertiary markets of animals are poorly organized and scattered, with very poor access to infrastructure like holding grounds, and water results in low quality of animals. In addition, rate of the transport is the highest cost for livestock trading as a result animals are trekked on foot to market and slaughterhouses, which leads to considerable loss of weight and exposure to physical injuries and illness which sometimes result in death of animals (Brasesco et al, 2019; Anteneh et al., 2010).

Illegal cross border trade: There is informal marketing of cattle, sheep, goats, and camels at border areas with Somalia, Kenya, Sudan, and Djibouti (Solomon, 2003). The annual outflow of live animals from Ethiopia to neighboring countries through the informal market is very high and the country loses a huge amount of foreign earning.

Lack of market information: Producers, traders, exporters and support giving institutions are constrained by shortage of market information to rely on for enhancing production, marketing and exports (Belachew and Jemberu, 2003). The limited access to information (market prices, quality requirements, standards, etc.) reduces their ability to be competitive and to access profitable markets (Brasesco et al, 2019). Hence producer depended on actual market day information or on market information obtained from relatives, friends or neighbors for prices and selling decisions (Dejene, 2016).

Traditional production system: The absence of a market-oriented production system results in inconsistent and uneven supply of animals to markets (Anteneh et al., 2010). Pastoralists consider their livestock as means of saving or capital accumulation as a result they sell their livestock when need arises for cash income or when shortage of feed and water occurs (Belachew and Jemberu, 2003). As a result, the effort to strategically produce 
for the market in terms of time, type and quality by adjusting and planning production to market needs is nonexistent (Brasesco et al, 2019). Furthermore, lack of strong and steady business linkages between suppliers and processors results in an inconsistent supply of quality animals to the market. Besides, there are limited or no commercial farms for supplying animal for meat production except the little effort in milk and poultry production systems.

Prevalence of trans-boundary animal disease: There are many livestock diseases in Ethiopia that create frequent livestock mortalities. The presence of livestock diseases apart from affecting the efficiency of production hampers export market development as a result of frequent bans by importing countries (Belachew and Jemberu, 2003). Consequently, the country has lost a substantial market share and foreign exchange earnings due to frequent bans by importing countries. Moreover, the animal health care service is at low level due to lack of animal disease diagnostic facility and limited professional for the public veterinary practice (Gebremariam et al., 2013).

Lack of livestock market extension service: In most areas extension workers are general practitioner and they lack knowledge about production techniques, input use, animal feeding and management, crossbreeding, postharvest handling and hygiene, business management and efficiency, as well as not well informed about the export market (Brasesco et al., 2019). However, producers informally know that animals collected from their area are exported to the Middle East but they did not have any information about who bought the animals, what quality parameters do buyers consider, the time they bought, and their purchasing system (Getachew et al., 2008). Besides, there are a number of initiatives and research activities towards improving the productivity of local breeds of small ruminants though it did not go far as expected and the research outputs did not reach into the real production system because of the poor extension service.

Lack of modern technologies and limited technical capacity: Slaughterhouses and abattoirs lack standardized facilities and the technologies used are limited to fresh and deboned meat products (Brasesco et al, 2019). In addition, there is a lack of skilled workers to utilize slaughtering facilities, which result in difficulties to fulfill sanitary and phyto-sanitary requirements to meet international market requirements and substitute imports.

Long and complicated market chain: There are four major marketing levels: farm level, primary markets, secondary markets, and tertiary/terminal markets. At the farm level, trade is carried out between producers and local traders (Alemayehu, 2011). The subsequent markets involve the smaller rural traders, larger traders, butchers, and consumers. The presence of these complex marketing channels affects meat and live animal exports (Getachew et al., 2008).

\subsection{Opportunities}

The large livestock population in Ethiopia with diverse and adaptable genotypes; diverse agro-ecologies for production of different types of livestock give important opportunities to influence the meat and live animals industry, particularly the export sector (Ameha, 2011).

High demand of animals by the local abattoirs: There are more than ten meat and edible offal processing abattoirs in Ethiopia. The export abattoirs are required to ensure a consistent and continuous supply of meat in order to meet the demand of the customers in the importing countries. Thus, there is a need for sustainable quantity and quality live animals supply to meet their processing needs in order to improve their efficiency and competitiveness.

Exports demand: The rapid growth in demand for meat products in the world represents a great opportunity for livestock resource-rich countries like Ethiopia. Export of meat to Middle Eastern countries is growing and Ethiopia have comparative advantage in terms of geographic proximity and the lowland breeds are highly demanded in the Middle East market due to their better taste and the organic nature of production (Belachew and Jemberu, 2003). There is also the possibility of expanding the export market to Asian markets which require halls-slaughtered, frozen, skin-off carcasses with less stringent hygienic regulations (Trade bulletin, 2011).

Domestic demand: Ethiopians with higher economic status will demand a greater amount of quality meat products. In this regard, according to the Ethiopian Livestock Master Plan 2015-2020 the projected domestic consumption requirements for red meat in 2020 will rise due to rapidly growing population, increasing urbanization, and rising incomes, presenting huge market opportunities for the red meat sub-sector.

Furthermore, government interest and support to the livestock industry; increasing number of export abattoirs and live animal exporters; the expansion of agro-industries and the increase of by-product feedstuffs processing are also the important opportunities influencing the meat and live animals industry in Ethiopia (Ameha, 2011).

\section{Conclusion}

Agriculture is the mainstay of Ethiopian economy; however, the agricultural and livestock production landscape is dominated by smallholders. The livestock sub-sector supports the livelihoods of a large share of the population and it is a major contributor to export earnings through the export of live cattle and small ruminants. While the livestock management system is predominated by extensive production systems i.e. mixed crop-livestock and 
pastoral/agro-pastoral that result in low production and low reproductive performance. Moreover, poor market infrastructure, lack of market information and extension service, trans-boundary disease outbreaks, long and complicated market chain, and illegal cross border trade are affecting the sub-sector performance to the economy and livelihood improvement. Although the increasing number of abattoirs, economic growth, geographic proximity to the Middle East countries, government interest and support to the sub sector are some of the opportunities.

Conflict of Interests

The authors have not declared any conflict of interests.

\section{Reference}

AGP-LMD (2013). End Market Analysis for Meat/Live Animals, Leather and Leather Products, Dairy Products Value Chains: Expanding Livestock Markets for the Small-Holder Producers. Agricultural Growth Program-Livestock Market Development (AGP-LMD).

Alemayehu, K (2011). Value Chain assessment of beef cattle production and marketing in Ethiopia: Challenges and opportunities of linking smallholder farmers to the markets. Livestock Research for Rural Development. 23(12):255-265. http://www.lrrd.org/lrrd23/12/alem23255.htm

Ameha S (2008). Sheep and Goat Meat Characteristics and Quality. Sheep and Goat Production Handbook for Ethiopia. Ethiopian Sheep and Goats Productivity Improvement Program (ESGPIP), Addis Ababa, Ethiopia.

Anteneh B, Tegegne A, Beyene F, Gebremedhin B (2010). Cattle milk and meat production and marketing systems and opportunities for market-orientation in Fogera woreda, Amhara region, Ethiopia. Improving Productivity and Market Success (IPMS of Ethiopian Farmers Project, ILRI, Addis Ababa, Ethiopia.

Asfaw N, Shahidur R, and Berhanu G (2011). Livestock Production and Marketing Development Strategy and Governance Division, International Food Policy Research Institute - Ethiopia Strategy Support Program II, Ethiopia, Working paper 26

Ashenafi F and Geoffrey E (2016). Ethiopia: Animal source food production and Marketing, Feed the Future Innovation Lab for Livestock Systems, University of Florida.

Ayele S, Assegid W, Jabbar M.A, Ahmed M.M and Belachew H (2003). Livestock marketing in Ethiopia: A review of structure, performance and development initiatives. Socio-economics and Policy Research Working Paper 52. Nairobi (Kenya): ILRI

Ayenew Y.A, Wurzinger M, Tegegne A, and Zollitsch W (2009). Handling, processing and marketing of milk in the North western Ethiopian highlands. Livestock Research for Rural Development. 21(7):97.

Belachew H and Jemberu E (2003). Challenges and opportunities of livestock marketing in Ethiopia, Challenges and opportunities of livestock marketing in Ethiopia. Proceedings of the 10th annual conference, Ethiopia Society of Animal production (ESAP), Addis Ababa, Ethiopia, 22-24 August 2002.

Brasesco F, Asgedom D, Sommacal V (2019). Strategic analysis and intervention plan for live animals and red meat in the Agro-Commodities Procurement Zone of the pilot Integrated Agro-Industrial Park in CentralEastern Oromia, Ethiopia. Addis Ababa. FAO. 108 pp.

CSA (2019). Agriculture Sample Survey 2018/2019 (2011 E.C), Report on Livestock and Livestock characteristics. Statistical Bulletin 588. Addis Ababa, Ethiopia.

CSA (2018). Agriculture Sample Survey 2017/2018 (2010 E.C), Report on Livestock and Livestock characteristics. Statistical Bulletin 587. Addis Ababa, Ethiopia.

CSA (2017). Agriculture Sample Survey 2016/2017 (2009 E.C), Report on Livestock and Livestock characteristics. Statistical Bulletin 585. Addis Ababa, Ethiopia.

CSA (2016). Agriculture Sample Survey 2015/2016 (2008 E.C), Report on Livestock and Livestock characteristics. Statistical Bulletin 583. Addis Ababa, Ethiopia.

CSA (2015). Agriculture Sample Survey 2014/2015 (2007 E.C), Report on Livestock and Livestock characteristics. Statistical Bulletin 578. Addis Ababa, Ethiopia.

Dejene T (2016). Assessment of cattle marketing practices in Guradamole woreda, Bale zone of Oromia regional state, Ethiopia, Int. J. Agril. Res. Innov. \& Tech. 6 (2): 36-41.

FAO (2019). The future of livestock in Ethiopia. Opportunities and challenges in the face of uncertainty. Rome. FDRE (2016). Growth and Transformation Plan II (2015/16-2019/20). Volume I: Main Text. Addis Ababa.

Gebremariam S, Amare S, Baker D, Solomon A and Davies (2013). Study of the Ethiopian live cattle and beef value chain. ILRI Discussion Paper 23. Nairobi (Kenya): ILRI

Getachew L, Hailemariam T, Dawit A and Asfaw N (2008). Live animal and meat export value chains for selected areas in Ethiopia. Constraints and opportunities for enhancing meat exports. Improving Market Opportinities. ILRI Discussion Paper 12. Nairobi (Kenya): ILRI

Kibrom T and Ibrahim W (2012). Consumption Patterns of Livestock Products in Ethiopia: Elasticity Estimates Using HICES (2004/05) Data. Development Strategy and Governance Division, International Food Policy 
Research Institute - Ethiopia Strategy Support Program II (ESSP II) Working Paper 38.

Negassa A and Jabbar M (2008). Livestock ownership, commercial off-take rates and their determinants in Ethiopia. ILRI Research Report 9. Nairobi (Kenya): ILRI

Shapiro B.I, Gebru G, Desta S, Negassa A, Nigussie K, Aboset G and Mechal H (2015). Ethiopia livestock master plan. Roadmaps for growth and transformation. ILRI Project Report. Nairobi (Kenya): ILRI

Tegegne A, Gebremedhin B, Hoekstra D, Belay B, and Mekasha Y (2013). Smallholder dairy production and marketing systems in Ethiopia: IPMS experiences and opportunities for market-oriented development. ILRI Working Paper 31. Addis Ababa (Ethiopia): ILRI

Trade bulletin 5 (2011). Ethiopia's Meat and Live Animal Export. Ethiopia Sanitary \& Phytosanitary Standards and Livestock \& Meat Marketing Program, quarterly bulletin, July issue, Addis Ababa (Ethiopia)

Yilma Z, Guernebleich E, Sebsibe A and Fombad R (2011). A Review of the Ethiopian Dairy Sector. FAO Sub Regional Office for Eastern Africa (FAO/SFE): Addis Ababa (Ethiopia)

Yisehak K (2008). Gender responsibility in smallholder mixed crop-livestock production systems of Jimma zone, South West Ethiopia. Livestock Research for Rural Development 20(1). 